\author{
ks. Jarosław Jagiełło \\ (D) https://orcid.org/0000-0001-7420-2973 \\ Uniwersytet Papieski Jana Pawła II w Krakowie
}

\title{
Jana Pawła II myślenie o solidarności
}

https://doi.org/10.15633/9788374389952.01

Książka Solidarność: człowiek w sieci zależności społecznych powinna się ukazać przed rokiem, gdy Polacy w rozmaity sposób przeżywali 40. rocznicę powstania szczególnej więzi międzyludzkiej, urzeczywistnionej niemal równocześnie zarówno w Niezależnym Samorządnym Związku Zawodowym „Solidarność", jak i w wielomilionowym polskim ruchu społecznym o tej samej nazwie.

\section{W hołdzie „Solidarności”}

Wybuch pandemii koronawirusa przekreślił pierwotne plany wydawnicze Interdyscyplinarnego Koła Naukowego Myśli Personalistycznej Jana Pawła II „TRADITIO”, które prężnie działa już od lat w Uniwersytecie Papieskim Jana Pawła II w Krakowie, w tym roku w szczególnej łączności z Wydziałem Filozoficznym Uniwersytetu Papieskiego Jana Pawła II. To opóźnienie w wydaniu książki, stanowiącej rezultat współpracy badawczej doktorantów uniwersytetu i przedstawicieli różnych dyscyplin w polskich ośrodkach naukowych, w niczym jednak nie zmienia intencji i pomysłu autorów pracy. Składają oni hołd „Solidarności” i patrzą na solidarność z perspektywy czasów nowych, w których dziś przyszło nam żyć. Patrzą przez pryzmat nowych wydarzeń, które prowokują wnikanie w społeczny wymiar rzeczywistości, jaką jest solidarność zarówno między pojedynczymi ludźmi, jak i rozmaitymi grupami ludzkimi.

Znamienne jest w tej książce to, że większość jej autorów łączy solidarność z chrześcijańskim stylem życia, choć przecież wiadomo, że chrześcijaństwo nie ma monopolu na jedynie ważne i powszechnie obowiązujące rozumienie solidarnego stylu życia, że przykład głębokiej solidarności międzyludzkiej niejednokrotnie dają także niechrześcijanie. Jednakże nie sposób zakwestionować tezy, że to właśnie personalistyczne rozumienie człowieka, 
w XX wieku tak mocno promowane właśnie przez myślicieli par excellence chrześcijańskich, w najbardziej znaczącej mierze odsłoniło wielkie dobro, jakie odkrywamy w pojęciu solidarności, a także w solidarnym stylu życia, które nigdy nie powinno być życiem przeciwko komuś, lecz zawsze dla kogoś.

Dlatego we Wprowadzeniu do niniejszej książki chciałbym raz jeszcze, przynajmniej w zarysie, powrócić do myśli personalistycznej Jana Pawła II. To przecież on - jako pierwszy w Polsce - wskazał na znaczącą rolę solidarności w rozumieniu człowieka i jego życia we wspólnocie. To przecież on jako papież tak mocno wyeksponował solidarność, bez której nie sposób zrozumieć ani najnowszych dziejów Polski, ani ożywionej nadzieją przyszłości współczesnego człowieka. Niech zatem przesłanie papieża z Polski będzie punktem wyjścia w przedstawianiu obrazów solidarności, jakie funkcjonują na kartach tej książki.

\section{Kościół i solidarność}

Wokół idei solidarności zogniskowało się nauczanie społeczne Kościoła rzymskokatolickiego co najmniej od roku 1891, a więc od ukazania się drukiem encykliki Rerum novarum papieża Leona XIII. Jednakże dopiero święty papież Jan Paweł II wyeksponował w aspekcie filozoficznym i teologicznym znaczenie antropologiczne idei solidarności. To właśnie ten papież „z dalekiego kraju” dokonał bardzo klarownej hermeneutyki tej idei. Szczególna jest ta hermeneutyka nie tylko dlatego, że Jan Paweł II przedstawił światu swoje bardzo wnikliwe rozumienie samego terminu „solidarność” w kontekście fenomenu ludzkiej pracy. Ta hermeneutyka jest również i dlatego szczególna, ponieważ papież z Polski dokonał ekspozycji rozumienia tego, w jaki sposób „solidarność”, zapisana zarówno wielką, jak i małą literą, została zrozumiana przez znakomitą część narodu polskiego, a zwłaszcza przez tych wewnętrznie wolnych Polaków, którzy zbudowali etos solidarności, czyli gniazdo, dom, w którym idea solidarności mogła się zadomowić na zawsze i z którego mogła promieniować na cały świat. Przestrzenią tego etosu jest najpierw Polska - nasza ojczyzna, matka karmicielka, tryskająca życiodajnymi sokami międzyludzkiej więzi, czyli solidarności ${ }^{1}$, która należy - jak podkreślił papież - do prawdziwego dziedzictwa narodowego Polaków² . Ale

1 Por. Z. Stawrowski, Solidarność znaczy więź, Kraków 2010, s. 120-152.

2 Por. Jan Paweł II, Homilia wygłoszona podczas mszy świętej, Sopot, 5 czerwca 1999 roku, https:// opoka.org.pl/biblioteka/W/WP/jan_pawel_ii/homilie/gdansk_05061999.html (12.09.2021). 
przestrzenią tego etosu jest równocześnie szczególne dzieło, a zarazem instytucja nieustannie wzywająca ludzi do solidarnego życia. W optyce papieskiej tym dziełem jest Niezależny Samorządny Związek Zawodowy „Solidarność”. To nam nim w sposób szczególny spoczywa zadanie i obowiązek wzywania do pielęgnowania i promocji solidarności w Polsce i w świecie.

\section{Solidarność w kontekście filozofii i teologii osoby}

Aby przynajmniej w niewielkiej mierze zrozumieć całe bogactwo treści, które Jan Paweł II wydobywa ze słowa „solidarność”, cofnijmy się na chwilę do roku 1969. Wtedy metropolita krakowski, kardynał Karol Wojtyła, wydaje drukiem swoje główne dzieło filozoficzne Osoba i czyn ${ }^{3}$ - świadectwo personalistycznej antropologii, głoszonej i reprezentowanej przez Jana Pawła II. W czasach agresywnego komunizmu ten polski personalista, etyk i metafizyk zarazem przypomina w swojej rozprawie, że każdy człowiek ma w sobie jedyną, szczególną i niepowtarzalną wartość, której na imię „godność osoby”. Podkreślając równocześnie, że każdy bez wyjątku człowiek jest osobą, Karol Wojtyła stanowczo stwierdza, że osoba nigdy nie jest czymś, ale zawsze kimś, i dlatego zawsze trzeba powtarzać, że bez wyjątku każda osoba jest podmiotem, a nie przedmiotem, że zatem zawsze jest ona celem, a nigdy środkiem do celu, i że stanowi podstawowy punkt odniesienia w budowaniu i doświadczeniu wspólnoty ludzkiej ${ }^{4}$. To właśnie w tym kontekście tematycznym pojawia się w ostatniej części Osoby i czynu słowo „solidarność”. Przez autora tej rozprawy solidarność jest rozumiana jako jeden z dwóch autentycznych, to znaczy właściwych tylko człowiekowi, czynów, dzięki którym urzeczywistnia się on w pełni jako osoba, która żyje nie dla siebie, nie dla osiągnięcia wyłącznie własnej doskonałości, lecz żyje przede wszystkim dla innych ludzi i dynamicznie uczestniczy w kreowaniu doskonałości innych, dając w ten sposób szczególny wyraz swego osobowego istnienia. Rdzeń solidarności odsłania się w uznaniu prawa człowieka, w uznaniu dobra wspólnego za własne dobro człowieka ${ }^{6}$. A więc czyn solidarności, postawa solidarna - w imię dobra wspólnego - mobilizuje człowieka nawet do ofiary z siebie, to znaczy na przykład do poświęcenia własnych korzyści, swojego indywidualnego

\footnotetext{
3 K. Wojtyła, Osoba i czyn, Kraków 1969.

4 Por. K. Wojtyła, Osoba i czyn, dz. cyt., s. 76 nn.

$5 \quad$ K. Wojtyła, Osoba i czyn, dz. cyt., s. 310.

6 Por. K. Wojtyła, Osoba i czyn, dz. cyt., s. 313.
} 
interesu dla innych. To właśnie w aktach solidarności objawia się prawdziwa twórczość człowieka, której źródłem nie jest wyłącznie on sam, lecz przede wszystkim jego bliźni, i to przede wszystkim ten inny - odnotowuje kardynał z Krakowa - jest pierwszym punktem odniesienia w uczestniczeniu osoby w życiu jakiejś wspólnoty, a więc w życiu z innymi i dla innych ${ }^{7}$. To dlatego Karol Wojtyła podkreśla, że solidarność jest podstawową zasadą życia społecznego.

Przedstawiona w Osobie i czynie myśl fundamentalna na temat idei solidarności w sposób wyjątkowy da o sobie znać w życiu papieża z Polski. Tę myśl Jan Paweł II, ubogacony doświadczeniem Polaków, wszechstronnie rozwinął i przedstawił jako jedną z najważniejszych zasad chrześcijańskiej koncepcji organizacji społecznej i politycznej rozumianej jako roztropna troska o dobro wspólne ${ }^{8}$. Uczynił to w swoich licznych pismach, w szczególności w encyklikach społecznych, w orędziach i homiliach. W sposób niezwykle atrakcyjny - jako mistrz medialnego przekazu - solidarność jako postawę moralną, jako cnotę ${ }^{9}$, czyli jako sposób rozumnego działania człowieka, usiłował on wpoić ludziom dobrej woli na całym świecie.

Po doświadczeniu wspólnoty wolności, jaka zawiązała się w Polsce podczas pierwszej pielgrzymki ojca świętego do ojczyzny w 1979 roku, po papieskim wspieraniu i obronie wielomilionowego ruchu tzw. pierwszej Solidarności, w szczególności zaś po nieustających wysiłkach Jana Pawła II na rzecz obrony NSZZ „Solidarność” i ratowania uwięzionych Polaków, niemal u schyłku komunistycznego reżimu w Polsce, czyli w roku 1987, Jan Paweł II sformułował dwie komplementarne względem siebie definicje solidarności. Pierwszą z nich przedstawił 12 czerwca w swoim kazaniu do świata pracy na polskim wybrzeżu, w Gdańsku, w kolebce „Solidarności”, gdzie wszystko się zaczęło. Drugą natomiast definicję zawarł 30 grudnia w encyklice Sollicitudo rei socialis, napisanej z okazji 20. rocznicy wydania encykliki papieża Pawła VI Populorum progressio.

Dostrzegając w słowach św. Pawła: „Jeden drugiego brzemiona noście” $($ Ga 6, 2) prawdziwą inspirację dla międzyludzkiej i społecznej solidarności, Jan Paweł II mówił: „Solidarność - to znaczy: jeden i drugi, a skoro brzemię, to brzemię niesione razem, we wspólnocie. A więc nigdy: jeden przeciw

7 Por. K. Wojtyła, Osoba i czyn, dz. cyt., s. 311-316.

8 Por. Jan Paweł II, Posynodalna adhortacja apostolska Christifideles laici, nr 42; Encyklika Centesimus annus, nr 10, 49; Encyklika Laborem exercens, nr 20.

9 Jan Paweł II, Encyklika Sollicitudo rei socialis, nr 40. 
drugiemu. Jedni przeciw drugim. I nigdy «brzemię» dźwigane przez człowieka samotnie. Bez pomocy drugich. Nie może być walka silniejsza od solidarności. Nie może być program walki ponad programem solidarności”"

Natomiast w encyklice poświęconej trosce o sprawy społeczne czytamy, że solidarność nie jest wyłącznie „nieokreślonym współczuciem czy powierzchownym rozrzewnieniem wobec zła dotykającego wielu osób, bliskich czy dalekich. Przeciwnie, jest to mocna i trwała wola angażowania się na rzecz dobra wspólnego, czyli dobra wszystkich i każdego, wszyscy bowiem jesteśmy naprawdę odpowiedzialni za wszystkich"11.

W tych dwóch określeniach solidarności, które są wyrazem szczególnego myślenia i działania człowieka, Jan Paweł II eksponuje trzy kierunki swojego patrzenia na solidarność pisaną wielką i małą literą. Jeden kierunek w pewnym sensie dotyczy przeszłości, bowiem papież wypowiada i pisze te znaczące słowa na temat solidarności jakby z perspektywy czasu, wszak z perspektywy roku 1987. W pamiętnych słowach: „Nigdy jeden przeciw drugiemu, nigdy jedni przeciw drugim” papież zdecydowanie eksponuje solidarność jako wyraz sprzeciwu wobec alienacji społeczeństwa. Ta alienacja była dziełem komunistycznej ideologii i zawsze jest - przypomina papież - dziełem każdego totalitaryzmu, który niejednokrotnie dokonuje zniszczenia w białych rękawiczkach. Komunizm uwikłany bez reszty w tzw. błąd antropologiczny, a więc w fałszywe rozumienie istoty człowieka ${ }^{12}$, starał się za wszelką cenę wyłączyć Polaków ze wspólnoty narodu. Tragicznym tego skutkiem było skłócenie Polaków, podzielenie ich na różne - nierzadko żądne niszczenia, złowrogie, nieufne względem siebie - klasy i ugrupowania, ufundowane przez komunistów na bazie niesprawiedliwości, zniewolenia i kłamstwa. A tymczasem „solidarność sumień” - jak mówił w słynnym wawelskim kazaniu ks. Józef Tischner ${ }^{13}$ - nie kreowała anonimowej masy, lecz wspólnotę zbudowaną na fundamencie prawdy, sprawiedliwości i wolności. Te trzy wartości i cnoty zarazem, podkreślał papież, były jedyną bronią i jedyną mocą ludzi solidarności, ludzi ciężkiej pracy, którzy istotę swojej życiowej misji odkrywali w dziele wzajemnej odpowiedzialności - tak, aby nikt sam nie dźwigał rozmaitych ciężarów swego życia, aby nikt nie był pozostawiony samemu

10 Jan Paweł II, Homilia wygłoszona podczas mszy świętej, Gdańsk, 12 czerwca 1987, http://nauczaniejp2.pl/dokumenty/wyswietl/id/750 (12.09.2021).

11 Jan Paweł II, Encyklika Sollicitudo rei socialis, nr 38.

12 Por. Jan Paweł II, Encyklika Centesimus annus, nr 13, 19, 23.

13 Por. J. Tischner, Etyka solidarności oraz Homo sovieticus, Kraków 1992, s. 12. 
sobie. Wobec takiej broni i takiej mocy oraz wobec takiej misji solidarności ideologia przeniknięta kłamstwem, zniewoleniem i niesprawiedliwością straciła swój sens - przemoc komunizmu i walka klas stały się absurdem. Za sprawą Jana Pawła II niejednokrotnie po raz pierwszy poznając - a najczęściej na nowo odkrywając - pojęcia i zasady społecznej nauki Kościoła, ludzie pracy w Polsce przede wszystkim pozbawili prawomocności marksistowską koncepcję pracy jako walki, a więc pracy chorej, pozbawionej sensu, wobec której jedyną zasadną postawą jest postawa sprzeciwu. Ale - jak pamiętamy - papież nie mówił o sprzeciwie w znaczeniu walki niszczącej drugiego człowieka, lecz o takim sprzeciwie, którego celem jest dobro człowieka, jego prawa, jego prawdziwy postęp i dojrzalszy kształt jego życia. I dlatego tak rozumiany sprzeciw i tak rozumiana walka są przede wszystkim wyrazem solidarności z człowiekiem i troski o przyrodzone mu prawa ${ }^{14}$.

Odsłaniając natomiast - w kontekście ekspozycji wysokiego poziomu chrześcijańskiego życia - najgłębsze źródła solidarności, Jan Paweł II w przemówieniu do młodzieży w Krakowie od razu wskazał na Jezusa Chrystusa, aby młodzież chrześcijańska w kraju „Solidarności” od razu mogła rozpoznać fundament własnej tożsamości. Dlatego mówił papież: „Nie ma takiego pokolenia chrześcijan, takiego pokolenia ludzkości, z którym Chrystus nie dzieliłby się sobą. Ostatecznie chodzi o to, żeby człowiek nie zagubił ludzkiego wymiaru swojego życia. Właśnie Chrystus daje mu ten ludzki wymiar swojego życia, jako Syn Boży. To jest niesłychana solidarność z człowiekiem. Wy się zastanawiajcie nad tym [...] co znaczy ta solidarność Boga z człowiekiem jako początek wszelkiej solidarności człowieka z człowiekiem. Jako początek wszelkiej solidarności ludzkiej. Solidarność Boga z człowiekiem sięgająca do tego, że daje siebie"15.

Ta refleksja na temat solidarności, którą papież - stojąc w oknie przy Franciszkańskiej 3 w Krakowie - podzielił się z młodzieżą, znajduje swoje dopełnienie kilka miesięcy później w dokumencie z 30 grudnia 1987 roku. Czytamy w nim: „Solidarność jest niewątpliwie cnotą chrześcijańską. Już w dotychczasowym rozważaniu można było dostrzec liczne punkty styczne pomiędzy nią a miłością, znakiem rozpoznawczym uczniów Chrystusa (por. J 13, 35). W świetle wiary solidarność zmierza do przekroczenia samej

14 Por. Jan Paweł II, Stolica Apostolska wobec problemów ludzkości. Do Korpusu Dyplomatycznego (12 I 1981), w: Jan Pawet II, Nauczanie społeczne, t. 4, Warszawa 1984, s. 20.

15 Jan Paweł II, Przemówienie do młodziė̇y przed siedzibą arcybiskupa w Krakowie, 10 czerwca 1987 roku, http://nauczaniejp2.pl/dokumenty/wyswietl/id/744 (12.09.2021). 
siebie, do nabrania wymiarów specyficznie chrześcijańskich całkowitej bezinteresowności, przebaczenia i pojednania. Wówczas bliźni jest nie tylko istotą ludzką z jej prawami i podstawową równością wobec wszystkich, ale staje się żywym obrazem Boga Ojca, odkupionym krwią Jezusa Chrystusa i poddanym stałemu działaniu Ducha Świętego. Winien być przeto kochany, nawet jeśli jest wrogiem, tą samą miłością, jaką miłuje go Bóg; trzeba być gotowym do poniesienia dla niego ofiary nawet najwyższej: «oddać życie za braci»" (por. $1 \mathrm{~J} 3,16)^{16}$.

Tak więc w pierwszej definicji ojciec święty faktycznie eksponował nie tylko początki, prawdziwe źródła solidarności, lecz równocześnie pokazywał jej nieprzemijający sens antropologiczny. W optyce papieskiej przecież to w odpowiedzialności za bliźniego - czasem posuniętej aż do oddania życia za innego - wyraża się prawdziwe jądro natury człowieka. Ta odpowiedzialność jako urzeczywistnienie solidarności nigdy nie jest człowiekowi raz na zawsze dana, lecz nieustannie zadana jako ugruntowany religijnie i wyjaśniony przez papieża, także z perspektywy teologicznej, wzorcowy model jedności rodzaju ludzkiego, z którego każdy naród i każda grupa społeczno-polityczna winna czerpać inspirację.

Mając to na uwadze, należy powiedzieć, że niespodziewanie znaleźliśmy się $\mathrm{w}$ przestrzeni problematyki poruszanej w drugiej definicji solidarności. W definicji tej solidarność - nie tylko ta z przeszłości, lecz również ta z teraźniejszości - jest przedstawiona jako par excellence kategoria moralna. Zauważyliśmy z pewnością, że papież mocno dystansuje się wobec czysto psychologicznego rozumienia solidarności, którą niejednokrotnie sytuujemy jedynie na poziomie życia uczuciowego. Tymczasem życie solidarne stanowi integralną część racjonalnej koncepcji istnienia człowieka. Właściwe kryterium weryfikacji takiego życia stanowi według papieża uznanie nienaruszalności godności osoby ludzkiej, a w rezultacie respektowanie praw człowieka, które właśnie w godności osoby mają swoje źródło i uzasadnienie. Kategorię praw człowieka papież jednoznacznie wiąże z kategorią dobra wspólnego. Tak więc i odpowiedzialność za słabszych i gotowość do dzielenia się z tymi, którzy są w potrzebie, głęboko włączona jest przez Jana Pawła II w orbitę praw człowieka i dobra wspólnoty. Zatem przyjmowanie postawy pasywnej względem prawdziwych ludzkich potrzeb niszczy tkankę społeczną i stanowi wyraz niezrozumienia lub lekceważenia dobra wspólnego. Podobnie ci,

16 Jan Paweł II, Encyklika Sollicitudo rei socialis, nr 40. 
którzy mają słuszne prawo do otrzymywania pomocy, także powinni wnosić jakiś swój wkład w budowanie i pomnażanie dobra wspólnego, a tym samym w budowanie wspólnoty.

Mowa papieża o udziale w dobru wspólnym, to znaczy w dobru wszystkich i każdego, odnosi się w równej mierze do pojedynczych osób, jak również do całych grup społecznych i narodów. Rzeczywistej solidarności ludzkiej towarzyszy przekonanie, podkreśla papież, że dobra tego świata przeznaczone są nie dla niewielu, lecz dla wszystkich ludzi. Dlatego według Jana Pawła II wszelkie działania o charakterze polityczno-społecznym powinny służyć dobru wszystkich, a nie tylko interesom określonej grupy ludzi. Zatem dominacja bogatszych nad biednymi czy silniejszych nad słabszymi jest według Ojca Świętego przykładem pogwałcenia zasady solidarnego życia, a w rezultacie przykładem łamania praw człowieka ${ }^{17}$.

Wspominając dzieje powstania ruchu solidarnościowego - a w szczególności wolnych związków zawodowych w Polsce - papież kreśli zarazem nie tylko ówczesny obraz solidarności, lecz także obraz solidarności jutra. Inaczej mówiąc, papież mówi również o koniecznym, niezbędnym warunku istnienia solidarności - jako wyzwania i jako zadania - nie tylko dziś, ale i w przyszłości. Ten warunek faktycznie przenika treść obu definicji papieskich, ale jest jakby ukryty w ich tle, niewypowiedziany explicite. Bez niego jednak baza życia solidarnego - opartego na prawdzie, wolności i sprawiedliwości - może przemienić się w swoje przeciwieństwo.

Ten warunek wybrzmiał w roku 1999, gdy papież znów przyjeżdża na polskie wybrzeże. Pełen zatroskania o przyszłość solidarności w Polsce, w Europie, w świecie, wypowiedział wtedy bardzo znamienne słowa: „Nie ma solidarności bez miłości”18. Nie ma przyszłości człowieka i narodu bez miłości, bez tej miłości, która przebacza, choć nie zapomina, która jest wrażliwa na niedolę innych, która nie szuka swego, ale pragnie dobra dla drugich; tej miłości, która służy, zapomina o sobie i gotowa jest do wspaniałomyślnego dawania. W myśl papieskiej uwagi o więzi między solidarnością i miłością wszyscy ludzie dobrej woli są wezwani do budowania przyszłości opartej na miłości Boga i bliźniego, są wezwani do budowania „cywilizacji miłości”.

17 Por. Jan Paweł II, Encyklika Sollicitudo rei socialis, nr 15-19.

18 Jan Paweł II, Homilia wygłoszona podczas mszy świętej, Sopot, 5 czerwca 1999 roku, dz. cyt. 


\section{Podsumowanie}

Przesłanie Jana Pawła II jest jasne i wyraźne: nie ma solidarności bez Boga i nie ma solidarności bez miłości do Boga i drugiego człowieka. Zauważmy krytycznie, że dziś wszyscy odmieniają słowo „solidarność” przez wszystkie przypadki, bardzo wielu wierzy w Boga i równie wielu z upodobaniem odwołuje się, także swoim działaniu, do przykazania miłości Boga i bliźniego. Również bardzo wielu chce mieć monopol na posługiwanie się słowem „solidarność”. Może właśnie z tej racji coś niedobrego dzieje się choćby z solidarnością wewnątrzeuropejską, także z solidarnością Polaków, z których jedni potrafią drugich nawet nienawidzić. Czy to brak dobrej woli? Czy to zapomnienie tego, czym jest solidarność w swej istocie? Czy to rezultat odłożenia nauczania papieskiego na półkę z książkami, po które niewielu sięga? Można mnożyć te pytania. A może jest tak, jak napisał ten, którego Jan Paweł II nazwał kiedyś filozofem solidarności ${ }^{19}$ : „Zło demoniczne działa. Nie działa jednak na ślepo, jak śnieżna lawina, kamień spadający z dachu czy złośliwa choroba. Demonizm wie w kogo, gdzie i kiedy uderzyć. Gdy uderza, uderza w wybranych ludzi i w wybrane miejsca. Przede wszystkim jednak uderza tam, gdzie przeczuwa rosnące dobro. Racją działania demonizmu jest odwet w stosunku do dobra za to, że odważa się być dobrem. [...] Nie jesteśmy demonami, [...] ale w naszym działaniu może się przejawiać fenomen demoniczności”20.

Jeśli tak rzeczywiście jest, to tylko Bóg, który jest najwyższym dobrem, który cały jest miłością, może nas uratować. I tylko On - prawdziwe źródło solidarności - może dać nam moc, abyśmy solidarnie zło dobrem zwyciężali.

$$
* * *
$$

Na zakończenie bardzo dziękuję wszystkim Autorom tekstów zamieszczonych w niniejszej publikacji. Dziękuję również jej Recenzentom. W szczególności dziękuję Pani Doktorant Karolinie Tytko, bez której zaangażowania ta książka nigdy by nie powstała. Dziękuję także Wydawnictwu Naukowemu Uniwersytetu Papieskiego Jana Pawła II za życzliwe włączenie tej publikacji w swój projekt wydawniczy.

19 Por. Jan Paweł II, Homilia wygłoszona podczas mszy świętej, Gdańsk, 12 czerwca 1987, dz. cyt.

20 J. Tischner, Spór o istnienie człowieka, Kraków 2011, s. 45. 
